\title{
Materiał językowy wykorzystywany w rehabilitacji słuchu pacjentów $z$ głuchotą postlingwalną
}

\section{Linguistic material used in auditory rehabilitation in patients with postlingual deafness}

\author{
Agnieszka Pankowska, Joanna Rostkowska \\ Instytut Fizjologii i Patologii Słuchu, Światowe Centrum Słuchu, Klinika Rehabilitacji, Warszawa/Kajetany \\ Adres autora: Agnieszka Pankowska, Światowe Centrum Słuchu, Klinika Rehabilitacji, ul. Mokra 17, Kajetany, \\ 05-830 Nadarzyn, e-mail: a.pankowska@ifps.org.pl
}

\begin{abstract}
Streszczenie
Pacjenci, którzy utracili słuch po okresie rozwoju mowy, wskazują, że jednym z ich największych problemów jest niemożność porozumiewania się z osobami słyszącymi. W procesie rehabilitacji (np. po zastosowaniu aparatów słuchowych i/lub implantu ślimakowego) powinni oni odbudować umiejętność słuchania i rozpoznawania sygnałów akustycznych oraz rozumienia mowy w ciszy i na tle dźwięków zakłócających bez udziału kanału wzrokowego, kontekstu sytuacyjnego czy odczytywania mowy $\mathrm{z}$ ust. W przedstawionym poniżej przeglądzie wybrano najistotniejsze doniesienia $\mathrm{z}$ literatury (artykułów, prezentacji), które odnoszą się do rehabilitacji słuchu dorosłych osób z postlingwalną utratą słuchu, a zwłaszcza do materiału słownego wykorzystywanego $\mathrm{w}$ trakcie ćwiczeń z pacjentami. W ramach działań rehabilitacyjnych wykorzystywane są sylaby, wyrazy, frazy, pojedyncze zdania i teksty dopasowane strukturalnie do konkretnych ćwiczeń i obejmujące zjawiska fonetyczne właściwe językowi ojczystemu pacjenta. W artykule przedstawiono sposób doboru materiału językowego oraz wybrane przykłady $\mathrm{z}$ codziennej praktyki klinicznej.
\end{abstract}

Słowa kluczowe: dorośli • implanty słuchowe • aparaty słuchowe • rehabilitacja słuchu

\begin{abstract}
Patients, who lost hearing after the period of development of speech, indicate that their greatest problem in daily life is the impossibility to communicate with hearing people. In the rehabilitation process (e.g. after being provided with hearing aids and/or cochlear implant) they should restore the ability to listen and discriminate acoustic signals and to understand speech in silence and against the background of noise without the aid of a visual channel, context or lip reading. In the following literature review we present the most important reports from literature (articles, presentations) that address rehabilitation of hearing of postlingually deafened adults, and, in particular, word material used in rehabilitation activities with patients. Rehabilitation exercises employ syllables, words, phrases, single sentences and texts with structure matched to a given exercise and incorporating phonetic material specific to the patient's mother tongue. This article presents the method of the selection of linguistic material and selected examples from everyday clinical practice.
\end{abstract}

Key words: adults • hearing implants • hearing aids • auditory rehabilitation

\section{Wprowadzenie}

Słuch daje człowiekowi możliwość pozyskiwania informacji o otaczającym go świecie, doświadczania przeżyć estetycznych (np. odbiór muzyki), komunikowania się. Okazuje się, że kiedy go tracimy, bardzo odczuwamy wynikające $\mathrm{z}$ tego faktu ograniczenia. Zarówno w medycynie, jak i pedagogice stosuje się określenia pochodzące z klasyfikacji głuchoty w odniesieniu do momentu powstania uszkodzenia słuchu i okresu rozwoju mowy. Według tej klasyfikacji wyróżnia się: głuchotę prelingwalną
- powstałą przed opanowaniem języka (do ok. 2-3 r.ż.), głuchotę perilingwalną - powstałą w okresie opanowywania języka (wiek 3-5 lat) oraz głuchotę postlingwalną powstałą po 5 r.ż. [1]. W swojej rozprawie habilitacyjnej Kurkowski przedstawił natomiast inny podział wiekowy: osoby prelingwalne - od 0,9 do 1 roku życia, perilingwalne - od 2 do 5 roku życia oraz postlingwalne - od 6 r.ż. [2]. W publikacjach europejskich i amerykańskich spotykane są tylko dwa określenia: głuchota prelingwalna (powstała przed 3 r.ż.) i postlingwalna (po ukończeniu 3 r.ż.) [3]. Jak wynika $\mathrm{z}$ powszechnego postrzegania problemu głuchoty, 
za najbardziej dotkliwe skutki utraty słuchu pacjenci uznają utrudnienia lub wręcz niemożność komunikowania się ze słyszącymi, co stanowi dominujący problem ich życia codziennego [4]. Pacjenci z głuchotą postlingwalną, którzy ze względu na postępujące ograniczenia w odbiorze sygnałów akustycznych i mowy zmuszeni zostają do „innego" radzenia sobie z porozumiewaniem się, opierając się na doświadczeniu zdobytym w okresie, gdy słuch funkcjonował prawidłowo, uczą się łączenia odbioru wzrokowego i słuchowego, kojarzenia, domyślania się treści informacji słownych. Warto $\mathrm{w}$ tym miejscu podkreślić, że dysponują oni językiem fonicznym, a więc systemem znaków i regul, które pozwalają na odbiór oraz nadawanie komunikatów słownych, co m.in. stwarza większe możliwości rehabilitacji [5]. Właśnie w procesie rehabilitacji (np. po zastosowaniu implantu ślimakowego) powinni oni odbudować umiejętność słuchania i rozpoznawania sygnałów akustycznych oraz rozumienia mowy w ciszy i na tle dźwięków zakłócających bez udziału kanału wzrokowego, kontekstu sytuacyjnego czy odczytywania mowy z ust.

W przedstawionym poniżej przeglądzie wybrano najistotniejsze doniesienia $\mathrm{z}$ literatury (artykułów, prezentacji, materiałów terapeutów), które odnoszą się do rehabilitacji słuchu osób dorosłych z postlingwalną utratą słuchu, a zwłaszcza do materiału słownego wykorzystywanego $\mathrm{w}$ trakcie ćwiczeń z pacjentami. Warto zaznaczyć, że w publikacjach poruszane są najczęściej kwestie struktury materiału (budowy sylab, wyrazów czy zdań), zaś konkretne przykłady można znaleźć np. w podręcznikach dla terapeutów wydawanych w formie książek, zestawów, broszur lub jako materiały poglądowe (tzw. demo na stronach internetowych) [6,7]. W artykule zamieszczone zostały pewne przykłady w wersji angielskiej lub polskiej, które pomogą odbiorcy zrozumieć zasady konstrukcji materiału językowego zaczerpnięte właśnie $\mathrm{z}$ takich źródeł.

\section{Proces rehabilitacji słuchu (etapy)}

W „Algorytmie doboru i dopasowania aparatu słuchowego" [8] znaleźć można informacje odnoszące się do działań rehabilitacyjnych. Wobec dorosłych pacjentów z postlingwalnym ubytkiem słuchu, który może być kompensowany z wykorzystaniem aparatów słuchowych, proponowane są działania obejmujące w pierwszej kolejności przeprowadzenie (cytując za autorem) testu zrozumiałości mowy, który stanowi pierwszą miarę jakości dopasowania aparatu (II wizyta pacjenta), a kolejno - w dalszej części algoryt$\mathrm{mu}$ - postępowanie określone mianem treningu słuchowego. Jego celem ma być nauczenie osoby słabosłyszącej rozpoznawania sygnałów akustycznych, budowanie motywacji do stałego korzystania z aparatu(ów), uświadomienie możliwości i ograniczeń urządzenia. Edward Hojan wskazuje na współpracę protetyka słuchu i psychologa oraz zauważa, że korzystną formą rehabilitacji słuchu jest również trening słuchowy w grupie [8]. Autor nie podaje jednak, co kryje użyty termin „trening słuchowy”, a jedynie, że jego celem jest „nauczenie osoby słabosłyszącej rozpoznawania sygnałów akustycznych” [8, s. 427].

W odniesieniu do pacjentów z ubytkiem słuchu, który może być leczony $\mathrm{z}$ wykorzystaniem systemu implantu ślimakowego, w literaturze wskazywanych jest 5 podstawowych etapów rehabilitacji słuchu: wstępny, detekcja (wykrywanie dźwięku), dyskryminacja (różnicowanie), identyfikacja (rozpoznawanie) oraz rozumienie mowy (swobodna rozmowa) $[9,10]$.

Etap wstępny o charakterze informacyjnym (obejmuje wiadomości o metodzie leczenia, zabiegu operacyjnym, podłączeniu procesora mowy i obsłudze systemu oraz założeniach programu rehabilitacji) nie zostanie w tym miejscu dokładnie omówiony, gdyż nie odnosi się w sposób bezpośredni do tematu artykułu. Począwszy od etapu wykrywania dźwięku aż po rozumienie mowy, działania wpisane w realizację kolejnych zadań wypełniane są zgodnie z zasadą stopniowania trudności i wpływają na dobór materiału językowego. Zasadne jest więc opisanie wymienionych etapów rehabilitacji słuchu.

Wykrywanie dźwięku (detekcja) obejmuje działania polegające na ocenie, czy pacjent słyszy, oraz sprawdzanie, czy może on rozpoznać początek i koniec sygnału akustycznego, liczbę sygnałów oraz kierunek, z którego dochodzi sygnał.

Dyskryminacja (różnicowanie) - na tym etapie pracy $\mathrm{z}$ pacjentem celem postępowania jest wypracowanie zdolności dostrzegania podobieństw i różnic między poszczególnymi sygnałami akustycznymi lub elementami mowy (zdaniami, frazami, wyrazami) na podstawie określonych cech (np. natężenia, barwy, obecności lub braku głosek itp.) bez nadawania im znaczenia.

Identyfikacja (rozpoznanie) - celem treningu słuchowego jest wypracowanie u pacjenta zdolności rozpoznania (skojarzenia ze znaczeniem) prezentowanego sygnału akustycznego, głoski, słowa, frazy lub zdania.

Rozumienie mowy - rozumienie słów, fraz, zdań lub tekstów oraz wykazanie sprawności słuchowo-poznawczej integrującej słuchanie i rozpoznanie w sytuacji komunikowania się (rozmowy). Trening słuchowy obejmuje ćwiczenia realizowane w sprzyjających warunkach akustycznych oraz na tle sygnałów zakłócających, w grupie rozmówców, z większej odległości nadawcy od odbiorcy.

Erber i Lind (1994) w swojej pracy przedstawili inne spojrzenie na założenia i cele rehabilitacji słuchu. Zwrócili oni uwagę na fakt, że dotychczas specjaliści prowadzący terapię pacjentów z głuchotą postlingwalną koncentrowali swoje wysiłki na zredukowaniu negatywnego wpływu ubytku słuchu na percepcję mowy. Stąd konsekwencją takiego podejścia była ocena i trening funkcji percepcyjnych, począwszy od detekcji fonemów, poprzez dyskryminację wyrazów, po identyfikację zdań i rozumienie mowy (narracji mówionej). Działania rehabilitacyjne koncentrowano więc na stymulacji i reakcji (odpowiedzi). Biorąc pod uwagę realne potrzeby tej grupy pacjentów, autorzy sugerują, że w rehabilitacji nacisk powinien być położony na język i komunikację. Natomiast audiolodzy i terapeuci mowy w pracy z osobami korzystającymi z aparatów słuchowych i/lub implantów ślimakowych odgrywać powinni rolę terapeutów komunikacji [11]. Ma to wpływ na wykorzystywanie podczas zajęć materiału i formuł właściwych codziennym sytuacjom komunikacyjnym (rozmowy), np. umieszczanie materiału słownego w pytaniu, a nie zdaniu oznajmującym, które trzeba tylko powtórzyć. 
Pacjent musi wówczas usłyszeć, zidentyfikować, zrozumieć oraz odpowiedzieć.

\section{Materiał językowy do stosowania w terapii logopedycznej (rehabilitacji słuchu)}

W ramach działań rehabilitacyjnych na wszystkich wymienionych etapach wykorzystywane są sylaby, wyrazy, frazy, pojedyncze zdania i teksty dopasowane strukturalnie do konkretnych ćwiczeń i obejmujące zjawiska fonetyczne właściwe językowi ojczystemu pacjenta. Wobec faktu, iż opracowanie przygotowane jest w języku polskim, stosownie do potrzeb opisu, zjawiska fonetyczne omawiane w dalszej części artykułu odniesione zostały do tego języka. Przykłady pochodzą natomiast zarówno z języka polskiego, jak i angielskiego.

\section{Sylaby}

Najczęściej powtarzającymi się przykładami sylab wykorzystywanych w rehabilitacji, zarówno do oceny efektów, jak i podczas ćwiczeń są sylaby nonsensowne o budowie: - spółgłoska-samogłoska-spółgłoska (ang. $C V C$ ), np. BEB, BAB, BUB, BIB itp.

- samogłoska-spółgłoska-samogłoska (ang. $V C V$ ), np. ASA, ABA, AKA itp.

Podczas ćwiczeń z samogłoskami wykorzystywane są monoftongi (tzw. proste samogłoski, które podczas wymowy nie zmieniają swojego brzmienia) oraz dyftongi (tzw. dwugłoski stanowiące połączenie dwóch dźwięków samogłoskowych o zmiennym przebiegu artykulacji, co wpływa na zmianę ich brzmienia). W języku polskim zjawisko to ma miejsce w wyrazach, np. maj, hydraulik, automat.

\section{Wyrazy}

Podstawowy podział dotyczy liczby sylab w wyrazie i na tej podstawie wyodrębnione zostały dwie podstawowe grupy: wyrazy jednosylabowe (ang. monosyllables) i wielosylabowe (dwu- lub więcej sylabowe; ang. bi-i polysyllables).

\section{Wyrazy jednosylabowe}

Najczęściej używane zarówno w rehabilitacji, jak i ocenie postępów wynikających z zastosowania danego urządzenia lub określonego treningu słuchowego są rzeczowniki, np. w języku polskim: dom, kość, twarz, śnieg itp., w języku angielskim: man, form, night, meat itp. Ponadto stosowane są wyrazy jednosylabowe, w których reprezentowane są zjawiska fonetyczne wpływające na brzmienie słowa, np. upodobnienia wewnątrzwyrazowe związane z koartykulacją głosek (antycypacją i perseweracją artykulacyjną), które dzielimy na wsteczne (w wyniku antycypacji artykulacyjnej), np. ssij (śśi,), lub postępowe (w wyniku perseweracji artykulacyjnej), np. krzak (kšak) [12]. Często spotykane są tzw. paronimy, czyli wyrazy podobne brzmieniowo, ale niespokrewnione ze sobą znaczeniowo, w których wykorzystano głoski opozycyjne pod względem określonej cechy dystynktywnej (dźwięczność - bezdźwięczność, ustność - nosowość, twardość - miękkość, opozycja ze względu na stopień zbliżenia narządów mowy, opozycja miejsca artykulacji), np. w języku polskim: dom - tom, mak - tak, miar - mar itp.; w języku angielskim zaś: can - cat, can - fan itp. czy szeregi wyrazów typu: seed, said, sod, sued [13].

Ponadto stosowane są tzw. anagramy, czyli w tym wypad$\mathrm{ku}$ wyrazy powstałe przez przestawienie wszystkich liter (głosek) występujących w wyrazów wyjściowym, np. kos - sok, krab - bark, wór - rów, odpowiednio w języku angielskim: shaw - wash, chill - leach, reach - chair [14].

\section{Wyrazy wielosylabowe}

Wyrazy zbudowane $\mathrm{z}$ więcej niż jednej sylaby. W praktyce klinicznej na etapie detekcji, kolejno dyskryminacji oraz identyfikacji stosuje się jako przykłady początkowo słowa o różnej liczbie sylab, np.: pałac - panoramiczny, radio reklama, matka - argumentacja, w języku angielskim: $f a-$ mous - unfortunately, police - permission [15], a następnie słowa o jednakowej liczbie sylab, np. ręka - koza, organizacja - sentymentalny lub w języku angielskim: investigation - organization, favorite - famous itp. [15] Stosując wspomnianą wcześniej zasadę stopniowania trudności, wybierane są wyrazy coraz bardziej podobne, zarówno pod względem długości, jak i brzmienia. W parach takich występują np. matka - maska, wtorek - worek czy w języku angielskim vacation - variation, mother - father itp. [15]. Przy doborze wyrazów wielosylabowych również wykorzystuje się zmiany zachodzące w słowach podczas ich wymowy, jak wspomniane powyżej upodobnienia, np. prośba (proźba) (udźwięcznienia), przerwa (pšerva), twardy (tfardy) (ubezdźwięcznienia) czy uproszczenia grup spółgłoskowych (osłabienie, a niekiedy całkowity zanik jednej z głosek) np. jabłka (japka), królewski (krulesk’i). W języku polskim spotykamy także wyrazy, w których pojawiają się głoski podwójne, tzw. geminaty, np. dookoła, zaakceptować, budda, winna itp. W ćwiczeniach (zarówno na poziomie dyskryminacji, jak i identyfikacji) wykorzystuje się je w parach $\mathrm{z}$ wyrazami zawierającymi tylko jedną z powtarzających się głosek, np. oda - odda, leki - lekki, cena - cenna.

Ciekawą grupę wyrazów stanowią zrosty słowotwórcze. Są to słowa zbudowane $\mathrm{z}$ dwóch morfemów, z których każdy ma samodzielne znaczenie, połączone tworzą natomiast wyraz o nowym znaczeniu. W polskich materiałach do ćwiczeń odnaleźć można m.in. takie przykłady: golibroda, winogrona, duszpasterz, bokser [16]. W języku angielskim są one określane jako tzw. spondeje. Są to np. birthday, armchair, stairway itp. [15].

Wyrazy jedno- i wielosylabowe stosowane są również w ćwiczeniach, w których materiał językowy stanowią frazy, zdania i teksty.

\section{Zdania}

W codziennej komunikacji posługujemy się częściej zdaniami lub równoważnikami zdań niż pojedynczymi wyrazami. Z praktyki klinicznej wynika, że podczas treningu słuchowego właśnie $z$ wykorzystaniem zdań obserwuje się, iż pacjenci z postlingwalnym ubytkiem słuchu, nawet krótko korzystający z urządzenia (aparatu słuchowego i/lub implantu ślimakowego), w celu rozpoznania treści przekazu najczęściej włączają skojarzenia, domysł, dotychczasowe doświadczenie językowe. Jest to strategia, jaką wypracowują w czasie, gdy pogarsza się im słuch, i wykorzystują, gdy 
adaptują się do słuchania po zastosowaniu odpowiedniego urządzenia wspomagającego słyszenie. Niezwykle trudne byłoby zebranie wszystkich możliwych kombinacji zdań wykorzystywanych podczas treningu słuchowego, dlatego skupiono się na najczęściej przedstawianych przykładach. W polskim programie rehabilitacji całkowitej utraty słuchu, który powstał w latach 1992-1997 we współpracy z czołowymi ośrodkami z Austrii, Niemiec, Szwajcarii i Belgii [17] i jest stale modyfikowany [18] stosownie do rozszerzenia kryteriów kwalifikacji do leczenia poprzez wszczepienie implantu ślimakowego [19], stosuje się następujące przykłady zdań:

1. Zdania o tym samym trzonie zakończone wyrazem różniącym się długością (różna liczba sylab), np.:

On ma motor.

On ma samochód.

Daj mi trochę mleka.

Daj mi trochę nadziei.

2. Zdania o jednakowej długości zawierające wyrazy o różnej barwie głosek, np.:

Mam pojechać do Małgosi.

Staś siedzi na krześle.

Zobacz ten sweter jest szary.

Mój brat lubi banany.

3. Zdania o różnej długości (złożone ze słów jedno-, dwui wielosylabowych), np.:

Czy ty wiesz, że dzisiaj jest święto.

Mam urodziny jutro.

Dzień dobry.

Chcę już stąd wyjść.

4. Zdania twierdzące i pytające (zmienna intonacja), np.: Zgubiłaś klucze na tej wycieczce.

Zgubiłaś klucze na tej wycieczce?

5. Zdania powiązane ze sobą tematem kluczowym i wskazówkami słownymi, np.:

temat: książki, słowa kluczowe: czytanie, autor, powieść Prawie skończyłam czytanie rozdziału.

Kim był autor tej książki?

Obecnie czytam powieść.

6. Zdania powiązane ze sobą wskazówką, frazą kluczową, np. „w ciągu lata...”:

W ciągu lata wiele osób wyjeżdża na wakacje.

W ciągu lata szkoły są zamknięte.

$\mathrm{W}$ ciągu lata powietrze jest bardzo suche.

7. Zdania powiązane tematycznie, np.:

Gdy mija lato, wiele drzew traci swoje liście.

Liście mogą zmieniać barwę.

Niektóre drzewa stoją zimą nagie.

8. Zdania niepowiązane ze sobą tematycznie (dowolne zdania wielowyrazowe).

Przedstawione powyżej przykłady zawarte są w ćwiczeniach przygotowanych w polskiej wersji językowej na bazie materiałów szwajcarskich (Cochlear) [14] i austriackich (MED-EL) [15]. Materiał w języku polskim przygotowany został przez zespół specjalistów początkowo związanych z Ośrodkiem Diagnostyczno-Leczniczo-Rehabilitacyjnym dla Osób Niesłyszących i Niedosłyszących „Cochlear Center” [16], a następnie pracujących w Instytucie Fizjologii i Patologii Słuchu [17]. Wobec faktu, że został on udostępniony specjalistom z „Cochlear Center” za zgodą autorów $\mathrm{w}$ celu wykorzystywania w codziennej praktyce bez prawa do publikowania, nie był wcześniej opisywany. Także ten raport zawiera jedynie wybrane, najważniejsze przykłady materiału językowego stosowanego $\mathrm{w}$ pracy $\mathrm{z}$ pacjentami korzystającymi z implantu ślimakowego.

\section{Teksty}

Obejmują zdania złożone ze słów jednosylabowych, dwusylabowych i różnosylabowych, proste i złożone, twierdzące, pytające, rozkazujące. Ich źrodłem są materiały opracowane przez terapeutów, ale również artykuły z codziennej prasy, opowiadania, książki itp. Poniżej przedstawiono przykład tekstu zbudowanego z przewagą słów jedno- i dwusylabowych:

Była noc. Staś nie spat. Za oknem wiał wiatr. Tu i tam czait się strach. Wtem „bach” coś spadło i to był straszny huk. Staś cicho wstał $i$ wzią kij. Starł z czoła pot, zrobił krok i potkną się o szkło. To kot rozbił sok. Staś poczuł, że saczy się krew. Rzucił kij w kąt i zdją but. Wtedy kot wskoczył na stół. Staś poczuł gniew i wydał głośny krzyk „a-psik” [15].

W swoim artykule Garstecki (1983) przedstawił przykłady zdań wielowyrazowych (średnia długość zdania to 7,3 wyrazu) o jednakowej konstrukcji: podmiot, orzeczenie, dopełnienie bliższe, dopełnienie dalsze z wyrażeniem przyimkowym, jako słowem kluczowym dla rozpoznania wyrazu [20]:

He repaired the motor on his boat.

I fixed the bell on my alarm clock.

She wore her boots in the storm.

We found some seashells at the beach.

Z tak zbudowanych zdań sporządzono następnie zestawy obejmujące po trzy zdania każdy. Drugie zdanie w zestawie to zdanie prezentowane wcześniej pojedynczo. Na końcu tego zdania umieszczono słowo klucz, po którym pacjent domyślał się tematu całego zestawu. Poniżej przykład takiego zestawu:

1. The man can fix any motor.

2. He repaired the motor on his boat.

3. The boat has a white and blue deck.

Autor zwraca uwagę na fakt, że pacjent na tym etapie, chociaż słuchał zdań, w praktyce wysłuchiwał już fragmentu (paragraph) o średniej długości 21,3 słowa [20]. Taka konstrukcja materiału (przykładów) przygotowuje pacjenta do wysłuchiwania, śledzenia i rozpoznawania coraz duższych fragmentów tekstów (w praktyce rozmów, dialogów, opowiadań).

\section{Prezentacja materiału językowego podczas ćwiczeń}

Podczas zajęć z pacjentami materiał językowy prezentowany może być odpowiednio w zestawach zamkniętych (z podpowiedzią w postaci ilustracji lub zapisanych na kartce przykładów słów, fraz lub zdań), półotwartych 
(z podpowiedzią $\mathrm{w}$ postaci ilustracji lub zapisanych na kartce tematów, haseł czy słów kluczowych) i otwartych (bez podpowiedzi w postaci ilustracji lub zapisanych na kartce przykładów słów, fraz lub zdań). Jak wynika z przedstawionych $w$ literaturze informacji, przykłady prezentowane są bezpośrednio (w czasie zajęć) przez kobiety lub mężczyzn bądź pochodzą z nagrań (również dokonanych przez kobietę lub mężczyznę). W pierwszym okresie rehabilitacji słuchu warunki akustyczne podczas prowadzenia treningu powinny sprzyjać pacjentowi (jedna osoba mówiąca, bez sygnałów akustycznych w tle). Podczas dalszej pracy korzystać należy z dźwięków tła, które stanowić mogą odgłosy rozmowy kilku osób czy też muzyka. Materiał językowy może być prezentowany począwszy od zdań, poprzez słowa, aż do poziomu sylab. Pacjent powinien odbierać tekst bez udziału kanału wzrokowego.

\section{Podsumowanie}

Przygotowanie materiału językowego i jego wykorzystanie $\mathrm{w}$ pracy $\mathrm{z}$ dorosłymi pacjentami $\mathrm{z}$ postlingwalnym ubytkiem słuchu powinno odpowiadać zarówno założeniom programów rehabilitacji, jak i, a może przede wszystkim, indywidualnym potrzebom odbiorców. Warto zwrócić uwagę na fakt, iż mimo opanowania języka ojczystego przed pogorszeniem lub utratą słuchu (częściową lub całkowitą) zasób słownictwa, znajomość reguł organizujących zdanie, zjawisk fonetycznych, które zachodzą wewnątrz wyrazów lub na styku wyrazów sąsiadujących w wypowiedzi, jest różna. W literaturze sygnalizowana jest konieczność uwzględnienia praktycznego celu rehabilitacji słuchu, jakim jest powrót przez pacjenta do aktywnego udziału w komunikacji słownej.

1. Osoby dorosłe z postlingwalnym ubytkiem słuchu za najbardziej dotkliwe skutki ograniczeń w odbiorze dźwięków i mowy uznają utrudnienia lub wręcz niemożność komunikowania się z osobami słyszącymi.

2. Zastosowanie leczenia, dobór aparatu słuchowego lub operacja wszczepienia implantu ślimakowego stanowi punkt wyjścia do rozpoczęcia rehabilitacji słuchu, czyli planowych i uporządkowanych w czasie działań określanych zwykle mianem treningu słuchowego.
3. W odniesieniu do pacjentów korzystających z aparatów słuchowych powstał "Algorytm doboru i dopasowania aparatu słuchowego", który zawiera wskazania do działań o charakterze monitorującym $\mathrm{z}$ wykorzystaniem testów zrozumiałości mowy (zgodnie z określeniem jego autora). Wobec pacjentów korzystających z implantów ślimakowych powstały programy rehabilitacji słuchu obejmujące kolejne etapy działań.

4. Materiał językowy powinien być dostosowany do etapów rehabilitacji słuchu, do kompetencji językowych i komunikacyjnych (słownictwo, wiedza językowa) pacjenta nabytych do czasu utraty słuchu oraz uwzględniać indywidualne predyspozycje i potrzeby pacjentów.

5. Materiał językowy powinien zawierać przykłady głosek, sylab, wyrazów i zdań, w których reprezentowane są zjawiska fonetyczne właściwe dla danego języka (języka ojczystego pacjenta).

6. W publikacjach związanych $\mathrm{z}$ rehabilitacją słuchu pacjentów niesłyszących i niedosłyszących z postlingwalnym ubytkiem słuchu znajdują się informacje dotyczące form prowadzenia terapii. $\mathrm{W}$ odniesieniu do materiału językowego stosowanego w pracy z pacjentami opisywane są zwykle testy zawierające sylaby, słowa, frazy i/lub zdania służące ocenie efektów korzystania z zastosowanego urządzenia wspomagającego słyszenie.

7. Konkretne przykłady materiału językowego odnaleźć można w podręcznikach dla terapeutów wydawanych w formie książek, zestawów, broszur lub jako materiały poglądowe tzw. demo na stronach internetowych.

8. Materiał językowy stosowany w Klinice Rehabilitacji Instytutu Fizjologii Patologii Słuchu podczas zajęć z osobami z postlingwalnym ubytkiem słuchu odpowiada zarówno etapom rehabilitacji słuchu, jak i zasadom postępowania stosowanym w różnych ośrodkach krajowych czy zagranicznych, związanych z rehabilitacją osób niesłyszących i/lub niedosłyszących.

Publikacja powstała $w$ zwiazku $z$ realizacja projektu pn. „Zintegrowany system narzędzi do diagnostyki i telerehabilitacji schorzeń narząów zmystów (słuchu, wzroku, mowy, równowagi, smaku, powonienia)" INNOSENSE, wspólfinansowanego przez Narodowe Centrum Badań i Rozwoju w ramach Programu STRATEGMED.

\section{Piśmiennictwo:}

1. Szczepankowski B. Wyrównywanie szans osób niesłyszących: optymalizacja komunikacji językowej. Siedlce: Wydawnictwo WSRP; 1998.

2. Kurkowski ZM. Audiogenne uwarunkowania zaburzeń komunikacji językowej. Lublin: Wydawnictwo UMCS; 2013.

3. Shapira NA, DelBello MP, Goldsmith TD, Rosenberger BM, Keck PE Jr. Evaluation of bipolar disorder in inpatients with prelingual deafness. Am J Psych, 1999; 156: 1267-9.

4. Albińska P. Problemy życia społecznego i zawodowego osób niedosłyszących i głuchych. W: Woźnicka E, red. Tożsamość społeczno-kulturowa głuchych. Łódź: Polski Związek Głuchych Oddział Łódzki, WSHE; 2011; 169-89.

5. Skarżyński H, Mueller-Malesińska M, Wojnarowska W. Klasyfikacje zaburzeń słuchu. Audiofonologia, 1997; 10: 49-60.

6. Strona internetowa firmy MED-EL: www.medel.com/pl/ resources-for-success-soundscape.
7. Strona internetowa firmy COCHLEAR: www.cochlear.com/ wps/wcm/connect/intl/home/support/rehabilitation resources/ useful-websites/for-teens-and-adults/.

8. Hojan E. Aparaty słuchowe. Wskazówki praktyczne. W: Audiologia kliniczna. Łódź: Mediton; 2005; 413-28.

9. Wojewódzka D. Umiejętności słuchowe osób ogłuchłych zaopatrzonych w implanty ślimakowe lub aparaty słuchowe. Nieopublikowana rozprawa doktorska. Warszawa: Akademia Pedagogiki Specjalnej; 2009.

10. Skarżyński H, Szuchnik J, Mueller-Malesińska M. Etapy rehabilitacji po wszczepieniu implantu ślimakowego. W: Implanty ślimakowe - rehabilitacja. Warszawa: Stowarzyszenie Przyjaciół Osób Niesłyszących i Niedosłyszących „Człowiek-Człowiekowi"; 2004; 56-72.

11. Erber N, Lind C. Communication therapy: theory and practice. Jara Monogr Suppl 27, 1994; 267-87.

12. Karczmarczuk B. Głoska w ciągu fonicznym. W: Wymowa polska z ćwiczeniami. Lublin: Wydawnictwo Polonia; 1987; 30-3. 
13. Fu Q-J, Galvin J, Wang X, Nogaki G. Moderate auditory training can improve speech performance of adult cochlear implant patients. ARLO, 2005; 6(3): 106-11.

14. Rehabilitation Manual Mini System 22. Praca zbiorowa. Cochlear Pty Limited; 1991.

15. Plant G. AUDITTRAIN. An auditory and Auditory-Visual Training Program. Therapist's handbook. Med-El GmbH; 2001.

16. Szuchnik Ji wsp. Tłumaczenie i opracowanie w polskiej wersji językowej materiału słownego stosowanego w programie rehabilitacji słuchu dorosłych pacjentów implantowanych z postlingwalnym ubytkiem słuchu na podstawie materiałów firmy MED-EL oraz COCHLEAR. Materiał niepublikowany. Warszawa: Ośrodek Diagnostyczno-Leczniczo-Rehabilitacyjny „Cochlear Center"; 1993/1994.

17. Skarżyński H, Szuchnik J, Mueller-Malesińska M. Polski program implantów ślimakowych. W: Implanty ślimakowe - rehabilitacja. Warszawa: Stowarzyszenie Przyjaciół Osób Niesłyszących i Niedosłyszących „Człowiek-Człowiekowi”; 2004, $46-50$.
18. Solnica J, Pankowska A. Rehabilitacja słuchowa pacjentów z częściową głuchotą korzystających z implantu ślimakowego - propozycja materiału językowego do zajęć. Doniesienie z praktyki logopedycznej. Nowa Audiofonologia, 2013; 2(1): 63-9.

19. Skarżyński H, Lorens A, Piotrowska A, Anderson I. Partial deafness cochlear implantation provides benefit to a new population of individuals with hearing loss. Acta Oto-Laryngologica, 2006; 126(9): 934-40.

20. Garstecki D. Auditory, visual, and combined auditory-visual speech perception in young and elderly adults. Jara Monogr $16 ; 1983 ; 221-33$.

21. American Speech-Language-Hearing Association. Connecting to communicate: delivering adult aural rehabilitation through telepractice. www.asha.org/telepractice.htm; 2013.

22. Adult Audiologic/Aural Rehabilitation. W: Audiology Information Series, praca zbiorowa. ASHA; 2011. 